to our understanding of the social transformation of medicine in America.

The medical profession's success was won by achieving a broad consensus among practitioners. Divided in the previous century, they rose to strength through the single-mindedness of the American Medical Association, among other professional vehicles. Taking advantage of their newly gained acclaim, they used the law to suit their ends. And the law gave them nearly complete authority over every aspect of medical delivery.

According to Starr, however, it was neither the advance of science nor the doctors' monopoly over medical practice alone that secured the profession's control:

Science may improve efficacy and productivity of a profession without making it rich and revered; knowledge must be transferred to authority, and authority into market power, before the gains from scientific advance can be privately appropriated by a profession . . . . If the medical profession were merely a monopolistic guild, its position would be much less secure than it is .... With widespread support, which they received because of complex changes overtaking the entire society, physicians were able to see social interests defined so as to conform to their own [my italics]. This was the essence of their achievement.

Paradoxically, the success of the medical profession may be its eventual undoing. Until quite recently it was almost solely the doctors themselves who determined the relationship of patients to hospitals, provision of drugs and payments for medical services. But while they have controlled most aspects of the marketplace, they have failed conspicuously to control costs. Doctors made health care lucrative, and large-scale enterprises have moved to take advantage. So while the medical profession has historically blocked government entry into health care by the front door, corporations have been moving in by the back. For example, according to the president of Humana (one of Fortune's 500 service companies) his organization aims at providing a uniform, reliable product, just like "MacDonald's hamburger coast to coast". By 1980, Humana, which had started with a few nursing homes, owned 92 hosptials and had $\$ 1.4$ billion in revenues.

The contemporary message of Starr's book is both clear and stark: the advent of corporations into medicine will undoubtedly further aggravate inequality in access to health care. "Profit-making enterprises are not interested in treating those who cannot pay . . . . the two-class system in medical care is likely to become only more conspicuous."

This is a radical book, written in a patrician style: scholarly and balanced, yet ultimately subversive. It is a major accomplishment. If Starr doesn't take it on as his next task, someone should surely use this book as a model to write a similarly perceptive history of science in America. $\square$

Robert Ubell, until recently the American publisher of Nature, is head of a science publishing house in New York.

\section{Inside yeast cells}

\section{J.M. Mitchison \& P.A. Fantes}

The Molecular Biology of the Yeast Saccharomyces: Metabolism and Gene Expression.

Edited by Jeffrey N. Strathern et al. Cold Spring Harbor Laboratory: 1983.

Pp.680. \$75 (US), $\$ 90$ (elsewhere)

THE Cold Spring Harbor Laboratory has done as well with this second part of its two-volume work on yeast as it did with the first on life cycle and inheritance (for review see Nature 92, 299; 1982). It is a distinguished collection of review articles which centre round metabolism and which show how much progress has been made since the last major review of the field in 1971 (The Yeasts, edited by A.H. Rose and J.S. Harrison, and published by Academic). Inevitably, some of the articles are already dated, especially in subjects like recombinant DNA technology. But in the slower-moving areas the reviews should be definitive for a respectable period.

A common theme is the powerful link between genetics, biochemistry and cell biology which is a characteristic of modern work on budding yeast. This is well brought out in the elegant article on secretion and surface assembly by Schekman and Novick. Another recurring problem is the complexity of many aspects of regulation and transport; anyone who has the temerity to think that regulation is simple should read the review by Oshima on the phosphatases.

The longest and perhaps the most imamino-acid and nucleotide biosynthesis. There are clear accounts of pathwayspecific and cross-pathway controls, and the tables and charts alone are (almost) worth the price of the book. Even so, at the end of more than a hundred pages we are told that "In no case do we know what the molecular basis of regulation is".

Those who work with budding yeast will find this book of great use. But it will be even more valuable to those who work with other fungi and with higher cells. More is known about budding yeast than about any other lower eukaryote and the natural question for those like ourselves who work with other yeasts is "what happens in budding yeast?". This book and its companion volume will tell us.

J.M. Mitchison is Professor and P.A. Fantes a Lecturer in the Department of Zoology, University of Edinburgh. pressive article is by Jones and Fink on
Understanding NMR techniques

K.A. McLauchlan

Nuclear Magnetic Resonance

Spectroscopy: A Physicochemical

View.

By Robin K. Harris.

Pitman: 1983. Pp.250. £17.50, \$34.95.

TO WRITE any book on NMR spectroscopy is to expose oneself to criticism - the subject is so wide, both in itself and in its applications, that tough decisions have to be made on the approach to be taken. The problems lie in identifying the intended readership and then in deciding the depth into which one should go. Such difficulties are compounded by the continual emergence of fresh concepts and experimental techniques.

Professor Harris has made a deliberate and brave choice to bias his book away from the straightforward, normal applications of NMR and towards introduction of the physical concepts involved in even the most modern experiments. As one would expect, the writing is particularly clear and the contents unusually well thought out.

The book is subtitled A Physicochemical $V i e w$, although for the most part a physical view is given with chemistry being used for illustration. Indeed physicochemical triumphs - including precise molecular geometry determination in solution and the nuclear polarization experiments which allow unique insight into free radical reaction mechanisms - are omitted deliberately. I was sorry too that a decision was made not to include density matrices, even though some of the subjects covered, notably exchange and two-dimensional spectroscopy, require them if the reader is to advance much beyond the level given here.

The book is somewhat didactic in style, with the origins of many equations being indicated only broadly; a dedicated magnetic resonance spectroscopist would need to consult more advanced monographs. Nor is it suitable as an introduction to NMR which an undergraduate could read to obtain an overview of the subject, its importance in chemistry and the analysis of simple spectra; it is too detailed for beginners. However for someone who has already progressed to that stage a firm basis for understanding in depth is provided and horizons are extended. Difficult ideas are met head on and illuminated. For those just getting to grips with nuclear magnetic resonance spectroscopy, the book will be most useful.

K.A. McLauchlan is a Lecturer in Physical Chemistry at the University of Oxford, and a Fellow of Hertford College. 